\title{
Diasporadical: In Ryan Coogler's 'Black Panther,' Family Secrets, Cultural Alienation and Black Love
}

Terri P. Bowles

The New School

Follow this and additional works at: https://digitalcommons.uri.edu/mgdr

Part of the African American Studies Commons, American Film Studies Commons, American Popular Culture Commons, Film Production Commons, Other Feminist, Gender, and Sexuality Studies Commons, Visual Studies Commons, and the Women's Studies Commons

\section{Recommended Citation}

Bowles, Terri P. (2018) "Diasporadical: In Ryan Coogler's 'Black Panther,' Family Secrets, Cultural Alienation and Black Love," Markets, Globalization \& Development Review. Vol. 3: No. 2, Article 7.

DOI: 10.23860/MGDR-2018-03-02-07

Available at: https://digitalcommons.uri.edu/mgdr/vol3/iss2/7

This Media Review is brought to you for free and open access by DigitalCommons@URI. It has been accepted for inclusion in Markets, Globalization \& Development Review by an authorized editor of DigitalCommons@URI. For more information, please contact digitalcommons-group@uri.edu. 
Diasporadical: In Ryan Coogler's 'Black Panther,' Family Secrets, Cultural Alienation and Black Love

\section{Markets, Globalization \& Development Review}
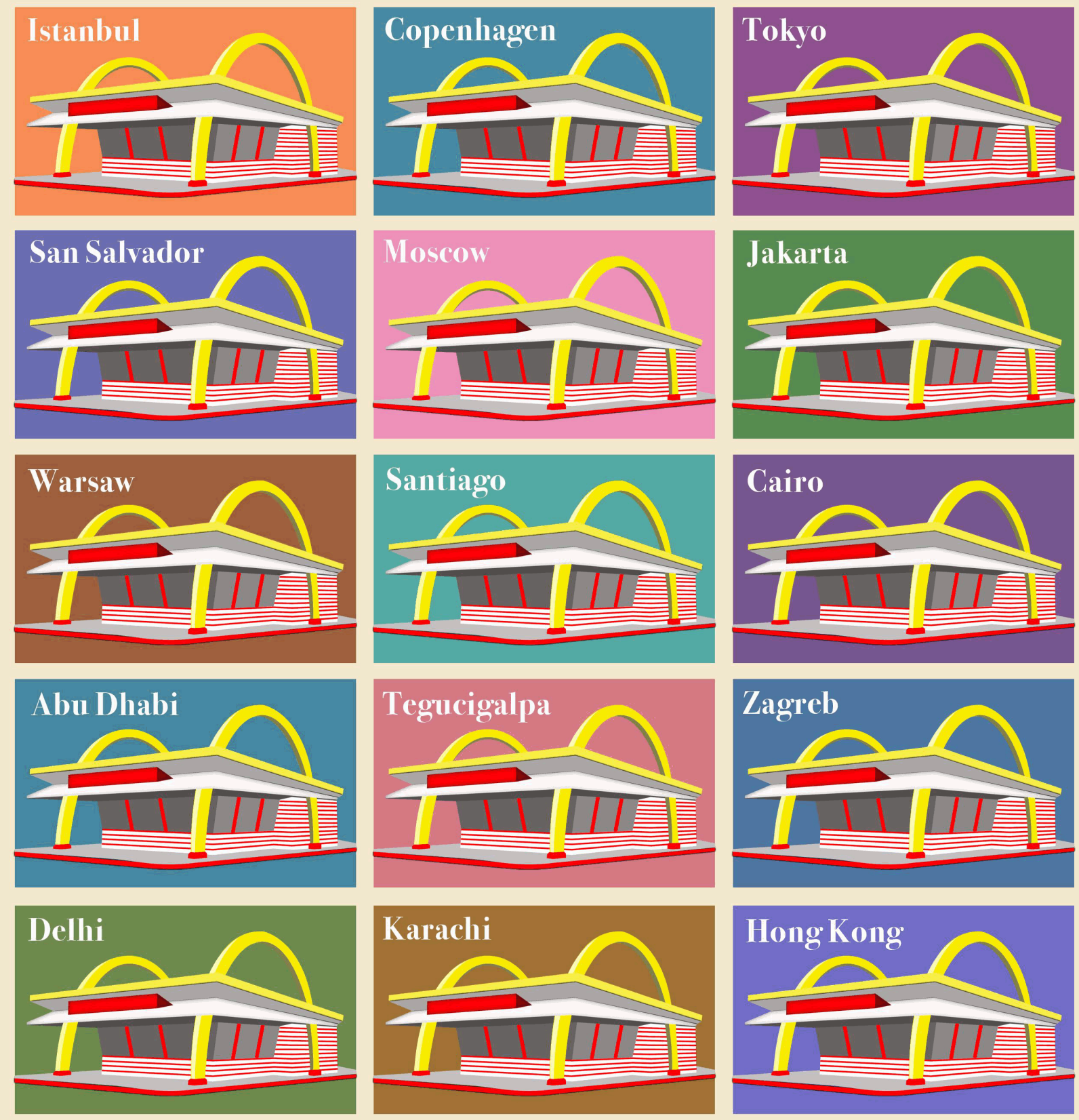

This media review is available in Markets, Globalization \& Development Review: https://digitalcommons.uri.edu/ $\mathrm{mgdr} / \mathrm{vol} 3 / \mathrm{iss} 2 / 7$ 


\section{Film Review}

\section{Diasporadical: In Ryan Coogler's Black Panther, Family Secrets, Cultural Alienation and Black Love}

\section{Overview}

Black Panther (2018), directed by millennial auteur Ryan Coogler, brims with love messages to continental Africa, tackles tension between Africans and American-born descendants of African slaves, and highlights women's empowerment in a tale with a classic hero at its core and an antihero at its heart. The story centers upon the mythical country of Wakanda, a nation masquerading as poor but which in reality is a rich, technologically advanced society powered by vibranium, a metal woven into the society's literal fabric. Vibranium confers its king with superheroic strength and its city with awe-inducing medical capabilities and scientific advancements. The film's central conceit concerns the challenge Wakanda's newly crowned king faces by an unexpected adversary, the brutal and wounded Erik Killmonger (Michael B. Jordan), and the discomfiting truth of his family's secrets. The young king, T'Challa (Chadwick Boseman), the Black Panther, must also decide whether to reveal his country's hidden riches and share them with a suffering worldmost urgently with the African diasporic populace wallowing in postcolonial/post-slavery communities marred by poverty and violence around the globe.

The computer-animated opening scene reveals Wakanda's origin story: a vibranium meteorite strikes the country, infusing the land with the powerful metal. Five warring tribes battle for supremacy until the panther goddess Bast reveals to a warrior an herb that, once consumed, confers superhuman strength. He becomes the first Black Panther, and the country's tribes line up behind him in a peace agreement - all but the Jabari, who cordon themselves off in their mountainous community and oppose the Panther tribe's dependence on technology. Wakanda hides from the rest of the world, presenting the false, stereotypically impoverished version of an African nation in an effort to protect its unique resources, and in the process evades the war and destruction that ravage other corners of the globe.

A fast-paced, unexpected second opening sequence establishes the parallel origin of T'Challa's foe, Erik Killmonger. In 1992 Oakland, one 
of the era's drug and gang hives - and birthplace of the 1960s revolutionary political organization the Black Panther Party - Killmonger's father, N'Jobu (Sterling K. Brown), is strategizing a plot with his confidant James (Denzel Whitaker) when there is a knock at his apartment door. In short order, two members of the Dora Milaje, the bald warrior-goddess security force of Wakanda, appear, preceding the blink-of-an-eye appearance of the Black Panther himself, King T'Chaka (Atandwa Kani). T'Chaka and N'Jobu, we learn, are brothers, and N'Jobu has been sent to live undercover in Oakland as a war dog. The king explains that a terrorist arms dealer named Ulysses Klaue (Andy Serkis) has stolen a cache of vibranium and murdered Wakandan citizens. Once it is revealed that N'Jobu's friend James is not an American but a Wakandan double agent named Zuri, N'Jobu is outed as a traitor assisting Klaue and is ordered by King T'Chaka to return to Wakanda and face punishment. N'Jobu, outraged by Zuri's betrayal, confronts him, and in the ensuing scuffle is killed by T'Chaka. The scene's closing shot is one of a boy and his friends outside on a basketball court, gazing skyward at the impossible sight of the Black Panther's Star Wars-like ship jetting off into the night sky. That boy is N'Jobu's son, Erik Stevens (later known as Killmonger).

These two setups - one introducing a never-colonized, wealthy African nation, and the other presenting an urban American community of poverty and violence - embody the film's divided heart. Oakland native Coogler, in plumbing the rarely explored histories and inextricable linkages between continental Africans and slavery's descendants, sets a ready stage for investigations into the guilt, pain and loss resulting from the African slave trade and its long aftermath. Despite the film's weighty context, however, Coogler ably walks the line between message movie and superhero flick, infusing the film with moments of passion and humor and the action, pyrotechnics and adventure expected of a Marvel (2018) film.

\section{A Fantasy Nation and Its Lost Son}

Back in present-day Wakanda, we learn that King T'Chaka has been killed in an explosion at the U.N. His son, Prince T'Challa, accompanied by General Okoye (Danai Gurira), leader of the Dora Milaje, sets out to share this news with his former lover Nakia (Lupita Nyong'o), a Wakandan spy who is in Nigeria on a rescue mission, and to ask her to return home for his crowning as the new king. On the ride home, T'Challa and Nakia, bathed in golden light, share a rarely seen moment between black lovers onscreen. They do not speak; their eyes meet as Nakia strokes T'Challa's hand through their interlaced fingers. The viewer cannot help but be struck 
by the intimacy of the scene - and by not only the beauty of the actors but also the rare sight of cinematography performed by filmmakers with an understanding of black skin tones.

Coogler liberally sprinkles such messages of \#blackexcellence throughout. T'Challa's sophisticated mother, Queen Mother Ramonda (Angela Bassett), and sister, tech genius Shuri (Letitia Wright), greet him with adoration and good-natured ribbing, respectively; they are beautiful and confident, wearing their royal status with ease. Coogler's fantastical nation glistens with symbolism and color. At T'Challa's coronation, the assembled tribes pulse with regal glamour, and it's clear the pains Coogler and his veteran costume designer Ruth $\mathrm{E}$. Carter have undertaken to ensure not simply authenticity but also next-level 'Black Is Beautiful' inspiration.

The film breaks ground in other ways. When we first meet adult Erik Killmonger, he and Klaue are executing the heist of a vibranium weapon misidentified in the British Museum as an artifact from Benin. He drips with swagger (and the confidence imbued by his elite MIT education); when he intercepts the curator's spiel about the weapon's origin - first correcting her then asking, "How do you think your ancestors got these?" - his bold invocation of colonial-era looting seems to catch her more off guard than the unfolding theft. He is a man vibrating with rage at both the legacy of colonialism and the loss of his rightful family legacy. Killmonger occupies the familiar cultural trope of the black young man raised (partly, in his case) without his father, and Coogler makes palpable his feelings of outrage and sadness and his thirst for vengeance.

\section{Black Excellence and Female Agency}

Back in Wakanda, the time for T'Challa's crowning has arrived. Zuri (Forest Whitaker), saved from death in Oakland by T'Chaka years ago and now a royal priest, prepares to crown T'Challa to much celebration and fanfare - until the secluded Jabari tribe emerge from their mountain. Their leader, the imposing M'Baku (Winston Duke), voices his profound displeasure with T'Challa's family's rule and offers a challenge. On the verge of losing to M'Baku, T'Challa only comes into his full power when his mother calls from the sideline, "Show him who you are!" Queen Ramonda's cry, heavy with profundity, awakens her son's inner warrior, and he locks the towering Jabari leader in a death grip, issuing a directive to yield. M'Baku hesitantly does so, ensuring the country's continuing rule by the Panther tribe - and also the ongoing alienation of the Jabari people. 
Following his challenge triumph, T'Challa is ritually buried and ascends to the spiritual plane where his deceased ancestors reside. He awakens from his "burial" to commune with his beloved father (John Kani). The two embrace, and T'Challa, overcome by the dueling emotions of joy and guilt over not having been able to save his father from the blast that took his life, kneels, tearfully apologizing. T'Chaka, issuing another poignant statement echoing Queen Mother's and reminding the audience of the collective greatness of Africa, commands his son to "Stand up! You are a king."

Yet Coogler's intonations of eminence are not limited to the men in the film. The women represent their tribes on the royal council, they are experts - and they are warriors. The striking and powerful Dora Milaje, resplendent in indigenous/Afrofuturistic armor, are the nation's elite fighting force. Wakanda's women not only have seats at the table, they influence the country's politics and literally (with Shuri's technological prowess) empower the nation. Coogler imbues the women with agency, invoking intersectional race and feminism theories in the development of Nakia's role as an educated leader of her River Tribe (Crenshaw et. al 1996; Hill Collins and Bilge 2016). Notably, Nakia is positioned by her people as a potential challenger to T'Challa's throne during his crowning ceremony, presenting the tantalizing prospect of a female Black Panther (and in the comics series, Shuri briefly occupies this role). Nakia has left her country to be a change agent, insisting on independence and not leaping at the opportunity to become queen, even as T'Challa pleads for her love. She is not simply an African version of the "strong black woman"; her determination to forge her own path is a fresh and unexpected twist. Nakia is also the film's conscience, debating with T'Challa the wisdom of Wakanda's isolationist politics - she urges him to open Wakanda's coffers and to aid communities in need; he responds that doing so would imperil the country's security. The implicit message within their debate whether and how black people of means should use their wealth and resources to uplift - is a long conversation throughout the diaspora; and it is given nuance and fresh perspective as mediated by the two estranged African lovers.

The women also rule the most dynamic, Marvel-esque fight scene in the film (Vanity Fair 2018). Traveling to South Korea with General Okoye and Nakia in tow to pursue Klaue and intercept a sale of vibranium between him and a CIA agent, Everett K. Ross (Martin Freeman), the king employs Nakia's insider knowledge and fluency in Korean to enter the casino where the sale is taking place. The trio, dressed to the hilt in red, black and green - the colors of the Pan-African flag - work their way in, 
Okoye's regal bald warrior pate hidden beneath a straightened Westernstyle wig, much to her humiliation and discomfort. Coogler's emphasis on the wig ("It's a disgrace!" Okoye bristles) makes for a dynamic statement by a black American male director, as wig-wearing (or hair straightening) among black women in American entertainment has typically been a requirement for employment. Once Klaue's band of fully armed thugs arrive, Nakia and Okoye realize the meeting is a setup, and after Ross and Klaue prepare to make the diamonds-for-vibranium trade, Okoye is noticed by one of Klaue's men and is forced to break her cover. Tossing the offending wig into his face, Okoye whips out her spear and fighting commences. The women of Wakanda hold their own, in full-length gowns and heels, contrasting femininity with fierceness (Vanity Fair 2018).

In what may be film's first female-led car chase, Okoye and Nakia take off in one vehicle, with Shuri, having been summoned by her brother to jump into the action, driving her lab's virtual high-tech vehicle. Once Klaue has been captured, he is detained at a CIA field office, where immediately following his questioning by Ross, Killmonger arrives, blowing through the building and shooting up the office. Ross is hit while saving Nakia from gunfire, and T'Challa decides he must be taken to Wakanda where he can undergo life-saving treatment. Amid the chaos, T'Challa notices that Killmonger (his face hidden behind an African mask stolen from the museum) is wearing the Black Panther tribe's vibranium ring on a chain around his neck. Once the group returns to Wakanda, leaving Ross in the capable hands of Shuri (whose statement, "Great, another broken white boy for me to fix" is both a nod to viewers familiar with the Marvel universe and a racial comeback for the ages), T'Challa is immediately greeted by W'Kabi (Daniel Kaluuya), Border tribesman, royal council member and husband of Okoye, who is desperate for the news of Klaue's death or capture. (His parents were killed by Klaue.) Once the king admits he was unable to satisfy the goal of the mission, W'Kabi's disappointment and anger foretell events that will shake the country's aura of stability.

\section{Liberation Theories and Postcolonial Rage}

After rescuing Klaue from the CIA, Killmonger reveals himself as a Wakandan before he shoots Klaue at point-blank range. Before firing, Killmonger explains his moniker, revealing his bloodlust and bodily scarification as a means to an end. Coogler again intersects African culture with black American rage, invoking revolutionary scholarpsychiatrist-philosopher Frantz Fanon's theories on colonial violence, its psychic toll and the appropriation of violence by colonized people (Fanon 2005). Meanwhile, King T'Challa confronts Zuri (Forest Whitaker), and the 
priest finally confesses the truth about the fatal confrontation between T'Chaka, N'Jobu and himself years earlier. Zuri drops a final sad detail, informing King T'Challa of the child his father left behind in Oakland in the wake of N'Jobu's killing.

Then comes the film's tipping point: Killmonger approaches W'Kabi and a group of Border tribesman, dragging the body of Klaue and suggesting himself as his killer. At an emergency royal council meeting, Killmonger, handcuffed, makes his claim to the throne, indicating that he intends to use Wakanda's vibranium weaponry to liberate the world's oppressed masses - as his father had intended - and to initiate global domination as a new world empire. King T'Challa tries to quickly dismiss Killmonger - but not before he proclaims his true identity: He is the forgotten Prince N'Jadaka, son of N'Jobu. Then W'Kabi holds high the vibranium ring, dangling it as both proof and a threat. The council determines the lost prince is within his rights to challenge for the throne. T'Challa, bereft of options, accepts.

Without preparations, the two hastily meet for the challenge. The powerful Killmonger, thirsty for revenge, outmaneuvers the king. Before he strikes the fatal blow, however, Zuri, breaking protocol, intervenes, pleading with Killmonger to take his life rather than his young ruler's. Killmonger cruelly refuses the trade, killing Zuri before hoisting T'Challa's body over the canyon into the river below. The new king is crowned, and the women - Princess Shuri, Queen Ramonda, and Nakia - are left to grapple with the tragic turn. In a critical scene highlighting the female characters' importance to the survival of the nation, Nakia seeks the essential aid of General Okoye in overthrowing the new leader, but learns she will not help them, as her loyalty lies with the throne of Wakanda, "no matter who sits upon it." Joined by Agent Ross (though his presence here weakens the story), the three then embark on a desperate mission to oust the new Black Panther.

During King N'Jadaka's ceremonial burial and ascent to the ancestral plane, there is no tree of life, no welcome by a royal bloodline. $\mathrm{He}$ is instead taken back to the Oakland apartment of his youth, where we witness the preteen Erik mourn over his father's dead body. As the boy looks through his deceased father's belongings, he is visited by N'Jobu's spirit. No tears for me? he asks his son. Erik, invoking his community's climate of brutal and pointless death, replies, "Everybody dies; it's just life around here." N'Jobu expresses his sorrow at being among Africa's lost ones, exiled in the impoverished lands of urban America. It is a wrenching scene, and the father and son's tangible, humanizing grief renders their motivations, if not methods, understandable. 
When King N'Jadaka awakens from his ceremonial burial, he is not quickened, as T'Challa had been, but enraged. Wrapping his muscular hand around the throat of the woman tending the precious herb, he demands it all be burned, declaring there will be no Black Panther after him. Hidden within the shadows, however, Nakia secretly plucks a single herb before the full crop is torched.

Addressing the council the following day, Killmonger angrily admonishes them for their lack of engagement with the world's suffering black communities, asking, "Where was Wakanda?" He announces his plan to upend the current world order through violent overthrow and to establish a new Wakandan Empire. In seeking to distill the philosophical distinctions between the two Black Panthers, numerous reviewers and commentators have described T'Challa's vision for Wakanda as aligning with the nonviolent doctrine of Martin Luther King, Jr., and Killmonger's as reflecting the "by any means necessary" position of Malcolm X. That reading, however, is too tidy and simplistic for Coogler's storyline; he has in fact described T'Challa as a separatist. It also ignores the realities of both leaders' evolutions in political thought, locking them into boxes that wrongly define King as anti-resistance and Malcolm X as pro-violence.

As the new leadership sets out to accomplish Killmonger's goals, Ramonda, Nakia and Shuri plan to offer the salvaged herb to M'Baku, the only viable challenger to Killmonger (although Ramonda first suggests Nakia take it herself). Climbing into the snowy Jabari lands, the group is quickly rounded up by tribesman and brought before M'Baku, where they share the news of T'Challa's death. The women offer M'Baku the herb; he responds by taking them to...the snow-covered body of T'Challa, discovered by Jabari fisherman in the river. They hastily feed him the herb, reviving him from his coma. During his passage back to the mortal world, T'Challa visits the ancestral plane once more, this time chiding his father and his other forebears for failing his cousin and for turning a blind eye to their people's despair - like Killmonger, asking, "Where was Wakanda?"

T'Challa's return leads to a full-scale war between the Dora Milaje and W'Kabi's Border Tribe - with General Okoye's combat skill edging out her husband's - and the climactic battle between the two Black Panther kings. As the cousins trade blows and accusations, the audience is pulled in a tug-of-war of political ideologies. T'Challa's barb to Killmonger that in trafficking in the violent tools of oppression he has become like his oppressors is particularly stinging, and pro-Killmonger fans have taken exception to it. Once Killmonger is felled by a wound to his abdomen, T'Challa carries him to a mountaintop where he can at last 
see the Wakandan sunset his father had promised he'd witness. T'Challa offers to save his life but Killmonger refuses, invoking his preference for death over bondage. His killing unleashed a torrent of real-world angst among black audiences, writers and theorists: Was Killmonger right? Was Coogler siding with Africans over African Americans? Is resistance futile? A different question rarely considered but worth pondering: Must black resistance be embodied in charismatic, hypermasculine forms?

\section{A New Heroism}

With King T'Challa back on the throne, and after he convinces Nakia to stay with him in Wakanda, we learn of his plans to add a rejoinder to the devastating events in Oakland that nearly destroyed his family and his country by building a community outreach center on the site of his uncle's murder. On a visit to Oakland, he does not avoid the boys on the basketball court, neither does he demur when they excitedly approach his ship. He is at last ready to engage with the world, most urgently with the young men like his cousin, who faced institutional obstacles to basic security and well-being. The last word goes to the Oakland boy (Moonlight star Alex Hibbert) marveling at the sight of a young black man in possession of such evident wealth, asking T'Challa the most existential of questions, neither rhetorical nor easily answerable: Who are you?

More than a comic book movie, Black Panther is a layered work of emotional depth, historical resonance and political significance. Ryan Coogler has offered a film that is part think piece, part big-budget thrill ride, and part social statement. While not perfect, it is a groundbreaking movie that presents a complex portrait of African lives; while there is strife, the characters who suffer are given weight and backstory, and while there is also wealth and exceptionalism, the privileged characters do not adhere to caricatured versions of the black elite. There is beauty and pain, pride and shame, and the story, while steeped in black cultural specificity, is broad enough to capture the Marvel moviegoing audience, all while engaging ideas of revolutionary struggle and while declaring unequivocally that black is indeed beautiful. Finally, although Coogler frames the conflict around two flawed male characters, it is the women - armed with Shuri's wit, Okoye's strength and Nakia's passion (and her humanistic political vision for Wakanda and the world beyond, as witnessed in the film's final scene) - who ultimately save the day. 


\section{References}

Black Panther (2018), Director: Ryan Coogler. Writers: Ryan Coogler and Joe Robert Cole. Distributed by Marvel Studios, Feb. 16, 2018.

Vanity Fair (2018), "Black Panther's Director Ryan Coogler Breaks Down a Fight Scene," "Notes on a Scene," (accessed June 20, 2018), [available at https://www.youtube.com/watch?v=SNHc2PxY8IY].

Marvel (2018), "Black Panther", (accessed June 20, 2018), [available at https://www.marvel.com/movies/black-panther].

Fanon, Frantz (2005), The Wretched of the Earth. New York, NY: Grove Paperback.

Hill Collins, Patricia and Sirma Bilge (2016), Intersectionality (Key Concepts). Cambridge, UK; Malden, MA: Polity Press.

Crenshaw, Kimberlé, Neil Gotanda, Gary Peller and Kendall Thomas, eds. (1996). Critical Race Theory: The Key Writings That Formed the Movement. New York, NY: The New Press. 